\title{
Pengembangan SDM pustakawan di Perpustakaan IAIN Kediri
}

\author{
Nurwarniatun \\ Pustakawan IAIN Kediri \\ email: nurwarni_ten@ymail.com
}

\begin{abstract}
This article explores the development of librarians 'resources in the library of IAIN Kediri as well as the obstacles faced by the library in developing librarians' resources. The research methods in the articles are qualitative, while the source data is field data obtained from observations, documentation and interviews with librarians and librarians at IAIN Kediri. The results of this study indicate that the development of librarians' resources at IAIN Kediri aims to enhance the competency of librarians in the areas of library management, processing and service. From 20132019 there were 29 human resources development activities, which can be grouped into: library management competencies, library processing competencies, IT competencies, Scientific writing competencies and Credit List Assignment List (DUPAK) and Information Literacy, and finally soft skills competency. Human resource development constraints are: librarians' competence in terms of corporate fundamentals, Librarians have not mastered the basic application of information systems, Librarians are not confident enough to follow-up, minimal HR development budgets, and the libraryis not autonomous in planning human resources development activities.
\end{abstract}

Keywords: development of librarians; librarian; library

\begin{abstract}
ABSTRAK
Artikel ini mengeksplorasi pengembangan SDM pustakawan di perpustakan IAIN Kediri serta kendala-kendala yang dihadapi oleh perpustakaan dalam mengembangan SDM pustakawan. Metode penelitian dalam artikel adalah kualitatif, sedangkan sumber datanya adalah data lapangan yang diperoleh dari pengamatan, dokumentasi dan wawancara dengan kepala perpustakaan dan para pustakawan di IAIN Kediri. Hasil penelitian ini menunjukkan bahwa pengembangan SDM pustakawan di IAIN Kediri bertujuan untuk meningkatkan kompetensi kepustakawaan pada aspek manajemen, pengolahan dan pelayanan perpustakaan. Mulai tahun 2013-2019 terdapat 29 kegiatan pengembangan SDM, kegiatan-kegiatan tersebut bisa dikelompokkan menjadi: kompetensi manajemen perpustakaan, kompetensi pengolahan bahan pustaka, kompetensi IT, Kompetensi penulisan karya ilmiah dan Daftar Usul Penetapan Angka Kredit (DUPAK) dan Literasi Informasi, dan terakhir kompetensi soft skills. Kendala pengembangan SDM yaitu: kemapuan pustakawan dalam hal dasar-dasar kepustakawanan sangat beragam, Pustakawan belum menguasai aplikasi dasar sistem informasi, Pustakawan tidak percaya diri sehingga minim tindak lanjut, minimnya anggaran pengembangan SDM, dan perpustakaan tidak otonom dalam merencanakan kegiatan pengembangan SDM.
\end{abstract}

Kata Kunci: Pengembangan SDM; Pustakawan; Perpustakaan

\section{A. PENDAHULUAN}

Sumber daya manusia memiliki peran penting dalam mewujudkan tujuan sebuah organisasi. Sebagai sebuah organisasi, perpustakaan meniscayakan adanya SDM pustakawan yang berkompeten sehingga tujuan diselengarakannya perpustakaan bisa dicapai. Hadirnya SDM yang berkualitas menjadi ujung tombak kemajuan perpustakaan. 
Perubahan lingkungan yang begitu cepat karena pengaruh perkembangan teknologi dan informasi yang bergerak cepat, dan tuntutan pemustaka yang selalu menghadirkan layanan yang serba cepat dan tepat menuntut SDM untuk cerdas mengantisipasi perubahan tersebut. Di sinilah diperlukan kompetensi, ketangguhan, dan keuletan sehingga mampu mengimbangi pergerakan kemajuan itu agar secara individu mampu bersaing (Suwarno 2016, 112).

Oleh karena itu perpustakaan harus melakukan berbagai upaya agar sumber daya manusia yang dimiliki dapat menggerakkan seluruh kegiatan perpustakaan, baik itu dalam hal pelayanan, pengolahan maupun kegiatan lainnya yang ada pada perpustakaan (Sudiarta 2016). Tanpa adanya reorientasi pengembangan pustakawan, perpustakaan tidak akan mampu untuk memenuhi secara maksimal tuntutan pemustaka, bahkan tidak mungkin perpustakaan akan ditinggalkan begitu saja. Inilah pentingnya pengembangan pustakawan sesuai dengan kebutuhan yang ada (Sutarno NS 2006, 115).

Laila Rahmawati menyatakan gambaran pustakawan ideal di era teknologi informasi mencakup: profesional, menguasai IT, penampilan yang bagus dan menarik, memiliki kemampuan inovatif dan kreatif, mampu melaksanakan menejemen informasi perpustakaan, berorientasi kepada pengguna, komunikator yang baik, santun dan tegas terhadap pelanggaran, pandai dalam menggalang dana, terakhir dirindukan oleh pengguna dan masyarakat sekitarnya (Laila 2012).

Potret pustakawan ideal di atas tidak hanya terbatas pada hard skill tetapi juga soft skill (sikap, perilaku, kepribadian) seperti kemampuan berkomunikasi dengan baik, mampu mencari jalan keluar atas persoalan pelanggaran, dan bisa menjadi mitra yang baik bagi konsumennya.

Sedangkan tujuan pengembangan SDM pustakawan adalah agar individu, dalam situasi kerja, dapat memperoleh kemampuan untuk mengerjakan tugas-tugas atau pekerjaan tertentu secara baik, dan juga memiliki kompetensi yang lain disamping kompetensi standar pada tugas teknis kepustakawanan, meningkatkan kinerja organisasi perpustakaan, mengantisipasi keterusangan ketrampilan, dan mempersiapkan pekerja sehingga ke depan dapat menjalankan tugas atau pekerjaan yang lebih tinggi jenjangnya(Suwarno 2016).

Memperhatikan tujuan di atas sudah selayaknya perpustakaan merencanakan pengembangan SDM pustakawan dengan baik sehingga kinerja perpustakaan semakin meningkat karena SDM yang ada telah disiapkan untuk mengantisipasi perkembangan organisasi dan tantangan perkembangan eksternal yang berjalan sangat cepat seiring dengan perkembangan teknologi informasi.

Perpustakaan IAIN Kediri sebagai salah satu perpustakaan lembaga pendidikan tinggi negeritelahmelaksanakan berbagai program pengembangan SDM pustakawan melalui berbagai kegiatan, di antaranyamengirimkan mereka untuk mengikuti pendidikan dan pelatihan Calon Pustakawan Tingkat Ahli (CPTA), Development of Library System Management (DELSMA) dan kegiatan-kegiatan pendidikan lainnya. Upaya-upaya itu dimaksudkan agar pustakawan memiliki kompetensi yang memadai untuk menunjang pengembangan perpustakaan IAIN Kediri di masa sekarang maupun masa-masa mendatang. Hasil dari upaya tersebut terlihat di antaranya terealisasinya citra positif pustakawan di luar IAIN Kediri, dengan diundangnya sebagian pustakawan IAIN Kediri sebagai narasumber pendidikan dan pelatihan tentang perpustakaan.Artikelini mengeksplorasi lebih lanjut pengembangan SDM pustakawan IAIN Kediri dan masalahmasalah yang mengitarinya. 


\section{B. TINJAUAN PUSTAKA}

Pengembangan perpustakaan tidak bisa dilepaskan dari kualitas SDM pustakawan. Karena semua kegiatan strategis perpustakaan dilakukan oleh pustkawan. Apalagi di tengah perkembangan IT saat ini posisi SDM yang berkualitas di perpustakaan sangat vital. Kemajuan teknologi informasi jika tidak didukung oleh pustakawan yang berkualitas hanya akan menjadi petaka. Teknologi yang awalnya mempermudah, akan mempersulit. Di sinilah pentingnya mengembangkan SDM pustakawan (Rifngati 2016).

Pengembangan sumber daya manusia adalah proses meningkatkan potensi produktifitas dari sumber daya tenaga kerja dalam hal pengetahuan, keterampilan dan kemampuan melalui mekanisme yang sesuai seperti: pendidikan dan pelatihan, konseling, perencanaan karir, kinerja atau penilaian diri, penghargaan atau hadiah dan Iain-lain. Pendidikan dan pelatihan memainkan peran penting dalam memperkuat kemampuan baik akademis dan profesional sumber daya manusia untuk memenuhi tujuan organisasi.

Secara singkat pengembangan sumber daya manusia merupakan sebuah proses yang dilakukan untuk meningatkan pengetahuan, keterampilan dan kemampuan melalui pendidikan ataupelatihan yang berkelanjutan yang bertujuan untuk mencapai tujuan organisasi. Pustakawan merupakan unsur perpustakaan. Pustakawan harus diarahkan dan dikembangan seperti perpustakaan. Pengembangan pustakawan dilakukansecara berkelanjutan dan terencana(Rizal Saiful-Haq 2005).

Secara eksplisit pasal 15 ayat 3 Undang-undang Nomor 43 Tahun 2007, penyelenggaraan perpustakaan terdiri dari komponen berikut:
a. memiliki koleksi perpustakaan;
b. memiliki tenaga perpustakaan;
c. memiliki sarana dan prasarana perpustakaan;
d. memiliki sumber pendanaan; dan
e. memberitahukan keberadaannya ke Perpustakaan Nasional (Undang-Undang Nomor 43 Tentang Perpustakaan 2007).

Sedangkan perihal tenaga perpustakaan pasal 29 undang-undang No. 43 tentang Perpustakaan menyatakan bahwa tenaga perpustakaan terdiri atas pustakawan dan tenaga teknis perpustakaan. Pustakawan harus memenuhi kualifikasi sesuai dengan standar nasional perpustakaan.

SNP 010:2011 menyatakan bahwa pustakawan adalah seseorang yang memiliki kompetensi yang diperoleh melalui pendidikan dan/atau pelatihan kepustakawanan serta mempunyai tugas dan tanggung jawab untuk melaksanakan pengelolaan dan pelayanan perpustakaan. Dalam hal pustakawan perguruan tinggi, pustakawan adalah tenaga yang berpendidikan serendah-rendahnya sarjana di bidang ilmu perpustakaan dan informasi, dan diberi tugas, tanggung jawab, wewenang, dan hak secara penuh oleh pejabat yang berwenang untuk melakukan kegiatan kepustakawanan di perpustakaan (Perpustakaan Nasional RI 2011).

Pasal 33 UU Nomor 43 Tahun 2007 tentang perpustakaan menyebutkan:

(1) Pendidikan untuk pembinaan dan pengembangan tenaga perpustakaan merupakan tanggung jawab penyelenggara perpustakaan.

(2) Pendidikan untuk pembinaan dan pengembangan sebagaimana dimaksud pada ayat (1) dilaksanakan melalui pendidikan formal dan/atau nonformal.

(3) Pendidikan untuk pembinaan dan pengembangan sebagaimana dimaksud pada ayat (2) dilaksanakan melalui kerja sama Perpustakaan Nasional, perpustakaan umum provinsi, dan/atau perpustakaan umum kabupaten/kota dengan organisasi profesi, atau dengan lembaga pendidikan dan pelatihan. 
Dengan demikian program pengembangan pustakawan menjadi tanggungjawab penyelanggara atau lembaga induk perpustakaan itu berada, oleh sebab itu setiap penyelenggara perpustakaan harus membuat perencanaan pengembangan pustakawan dengan mempertimbangkan kondisi SDM pustakawan, tantangan kompetensi yang dihadapi di lapangan dan ketersediaan dana yang memadai.

Pengembangan kualitas sumber daya manusia meliputi: keterampilan dan sikap, dengan mengirimkan mereka untuk mengikuti pendidikan formal maupun informal serta pelatihan dalam pengembangan jabatan. Sedangkan dalam hal kuantitas lebih mengacu kepada kebutuhan meliputi penambahan dan pengurangan jumlah sumber daya manusia di perpustakaan yang berkaitan dengan efektif dan efesien dalam mengelola perpustakaan(Sutarno NS 2006).

Dari beberapa pendapat tersebut, pembinaan dan pengembangan sumber daya manusia di perpustakaan merupakan sebuah proses menciptakan sumber daya manusia yang lebih berkualitas dengan cara peningkatan pengetahuan, keterampilan dan kemampuan pustakawan melalui pendidikan atau pelatihan dalam mencapai tujuan organisasi. Pembinaan dan pengembangan sumber daya manusia di perpustakaan sama seperti pembinaan dan pengembangan perpustakaan maupun koleksi dan dilakukan secara terus menerus dan berkelanjutan serta mengikuti perkembangan ilmu pengetahuan dan teknologi yang mengacu kepada efektif dan efesien dalam mengelola perpustakaan.

\section{Kualifikasi Pustakawan Perguruan Tinggi}

Kualifikasi pustakawan perguruan tinggi meliputi:

1. Memiliki kemampuan untuk menjadi mitra bagi pengguna. Pengguna perpustakaan PT adalah dosen, peneliti, mahasiswa dan tenaga kependidikan, seorang pustawakan harus berperan sebagai mitra, yang berdiri sejajar dengan para stakeholder, sehingga ia harus pro aktif tidak menunggu sebagaimana petugas perpustakaan. Jadi harus ada perubahan mindset, dari petugas menjadi mitra yang berdiri sejajar. Untuk sampai pada posisi mitra, pustawakan harus terus mengembangkan diri melalui berbagai program pendidikan dan pelatihan, serta membuka diri terhadap perubahan dan perkembangan ilmu pengetahuan yang sedang menjadi trend saat ini.

2. Keahlian Melek Informasi. Pustakawan PT harus melek (literate) informasi, karena perpustakaan perguruan tinggi sangat dinamis seiring dengan perkembangan TIK. Kemampuan menelusur informasi dengan cepat dan mengemasnya agar dengan mudah bisa dimanfaatkan oleh para penggunanya adalah keniscayaan. Termasuk dalam kemampuan ini tren pengguna yang selalu ingin sesuatu yang praktis, cepat, sehingga kemampuan akan perpustakaan digital adalah kompetensi yang tidak bisa ditawar.

3. Keahlian berbagaijenis layanan perpustakaan. Pustakawan perguruan tinggi sebagai unsur penting dalam perpustakaan harus paham dan mahir dalam memberikan setiap layanan yang ada di perpustakaan.

Di samping itu, ketrampilan lain yang harus dikuasai oleh pustakawan PT adalah kemampuan dalam berkomunikasi. Melalui kemampuan berkomunikasi yang baik, pustakawan dapat mengetahui informasi apa saja yang dibutuhkan oleh pemustakanya.(Rifngati 2016)

\section{Tujuan Pengembangan SDM}

Pengembangan SDM pustakawan bertujuan agar individu, dalam situasi kerja, dapat memperoleh kemampuan untuk mengerjakan tugas-tugas atau pekerjaan tertentu secara 
baik, dan juga memiliki kompetensi yang lain disamping kompetensi standar pada tugas teknis kepustakawanan, seperti pengadaan, pengolahan dan pelayanan.

Tujuan lain dari pengembangan SDM adalah dalam rangka meningkatkan kinerja organisasi perpustakaan. Pengembangan SDM dalam bentuk pendidikan dan pelatihan dimaksudkan agar kinerja organisasi dalam semua level meningkat, oleh karena itu perlu adanya pemetaan kemampuan SDM sehingga program-program pengembangan bisa direncanakan dengan baik. Tujuan berikutnya adalah mengantisipasi keterusangan ketrampilan. Ilmu dan skill selalu mengalami perkembangan, termasuk di dalamnya bidang perpustakaan dan informasi. Pengembangan SDM dengan demikian adalah sebuah keniscayaan, sehingga kemampuan SDM pustakawan selalu update dan selaras dengan perkembangan ilmu pengetahuan dan skill.

Terakhir pengembangan SDM dimaksudkan untuk mempersiapkan pekerja sehingga ke depan dapat menjalankan tugas atau pekerjaan yang lebih tinggi jenjangnya(Suwarno 2016). Tantangan kompleksitas tugas dan perkembangan orgnasasi di masa mendatang harus dijawab dengan SDM yang berkualitas, pada poin inilah penyiapan SDM dengan berbagai ilmu dan skill tidak bisa ditawar, karena organisasi apapun dia termasuk perpustakaan harus semakin menunjukkan kinerjanya dalam melayani penggunanya. Dengan demikian tujuan pengembangan SDM diarahkan untuk mewujudkan perbaikan, peningkatan, membuat inovasi dari program kegiatan atau rencana yang sudah ada sebelumnya, sehingga terjadi pengembangan yang dinamis dan terus menerus.

\section{Kegiatan Pengembangan SDM}

Pengembangan pustakawan dapat dilakukan melalui pendidikan,baik pendidikan formal bidang ilmu perpustakaan, non-formal tentang bidang perpustakaan serta informal yang lebih kepada pengembangan diri sendiri pustakawan.

\section{Pendidikan Formal}

Pendidikan formal dapat ditempuh di lembaga-lembaga pendidikan tinggi dengan jenjang diploma, sarjana dan magister atau doktor di bidang perpustakaan, dokumentasi dan informasi. Baik lembaga pendidikan dalam maupun luar negri yang menyelenggarakan program bidang ilmu perpustakaan, dokumentasi dan informasi.

2. Pendidikan Non Formal

Pendidikan non-formal dapat ditempuh dengan cara mengikuti pendidikan dan pelatihan (diklat), penataran (up grading), symposium, seminar, lokakarya, kursus, magang (on the job training), studi banding dan lain sebagainya yang tentunya bersifat pendidikan non-formal. Pendidikan non-formal merupakan salah satu jawaban bagi peningkatan kualitas bagi pustakawan apabila pendidikan formal tidak memungkinkan dilakukan untuk kegiatan pembinaan pustakawan

3. Pendidikan Informal

Kegiatan yang dapat dilakukan seperti belajar sendiri, terutama membaca dan belajar dari pengalaman diri sendiri serta orang lain atau sering melakukan diskusi secara informal dengan sesama pustakawan. Sedangkan kegiatan lainnya yang mampu menunjang pendidikan informal antara lain seperti berkarya wisata, bertukar pengalaman, kunjung mengunjungi antar sesama pustakawan atau kunjungan kerja pustakawan(Rachman Hermawan S and Zen 2006).

Senada dengan Zen, Nugrahani menyatakan bahwa pengembangan SDM pustakawan dilakukan melalui berbagai kegiatan (Nugrahani 2017, 4): 
1. Peningkatakan pengetahuan dilakukan melalui pendidikan formal maupun informal dengan memberikan kesempatan kepada pustakawan untuk studi lanjut pada jenjang yang lebih tinggi, atau mengirimkannya dalam berbagai kegiatan pelatihan/workshop/ seminar atau kegiatan ilmiah lainnya sesuai dengan bidang tugas masing-masing pustakawan

2. Peningkatakan kemampuan dilakukan dengan mengirimkan mereka dalam kegiatan pelatihan kompetensi khusus yang diperlukan dalam menunjang kegiatan di perpustakaan, seperti pelatihan desain web perpustakaan, pelatihan aplikasi manajemen perpustakaan dll.

3. Peningkatakan hard skill dan softskill. Hard skill seperti kemampuan dalam penguasaan bahasa asing, kemampuan pemanfaatan IT untuk menunjang tugas-tugas di perpustakaan. sedangkan soft skill meliputi: ketrampilan menyampaikan pendapat, pemikiran, gagasan dalam bentuk lisan dan tulisan; ketramplilan berkomunikasi; ketrampilan leadership, tim building, dll.

Pengembangan diri sendiri oleh pustakawan tidak menutup kemungkinan dilakukan oleh sesama pustakawan tetapi dapat dilakukan antara pustakawan dengan pemustaka. Pengembangan diri ini dilakukan dengan cara saling berbagi pengetahuan dari hasil seminar, workshop atau pelatihan dan dari buku-buku yang telah dibaca oleh pemustaka atau pustakawan. Dengan cara ini pustakawan diharapkan mampu mengambil manfaat dan dapat mengembangkan pengetahuannya.

\section{METODE PENELITIAN}

Penelitian ini adalah penelitian kualitatif, yaitu berusaha mendeskripsikan pelaksanaan pengembangan SDM pustakawan di Perpustakaan IAIN Kediri. Sumber data penelitian ini adalah data lapangan yang diperoleh dari hasil pengamatan dan dokumentasi pelaksanaan pengembangan SDM pustakawan. Selain itu, data juga diperoleh melalui wawancara dari kepala perpustakaan dan para pustakawan di IAIN Kediri. Pemilihan sumber dalam hal ini, menggunakan teknik purposivesampling. Peneliti juga menggunakan sumber pendukung berupa data tertulis (dokumen) yang diperoleh melalui Panduan Perpustakaan, SOP Perpustakaan, dan dokumen-dokumen lainnya

\section{HASIL DAN PEMBAHASAN}

Perpustakaan IAIN Kediri adalah perpustakaan yang berada di bawah naungan IAIN Kediri dan merupakan salah satu unit penunjang dalam mencapai tujuan IAIN Kediri. Sebagai bagian integral dari IAIN Kediri, perpustakaan diselenggarakan dengan tujuan untuk menunjang pelaksanaan program IAIN Kediri sesuai dengan Tri Dharma Perguruan Tinggi, yaitu pendidikan dan pengajaran, penelitian dan pengabdian pada masyarakat.

Dengan demikian tugas utama Perpustakaan IAIN Kediri adalah mendukung pelaksanaan Tri Dharma perguruan tinggi melalui pemberian layanan sumber informasi dengan cara merencanakan, mengumpulkan, mengolah, menyusun dan menyebarluaskan bahan pustaka yang mencakup semua disiplin ilmu yang dikembangkan oleh IAIN Kediri(Komarudin et.al. 2019, 7).

Pada tahun 2019, Perpustakaan IAIN Kediri memiliki 12 pustakawan, 2 orang memiliki latar belakang S1 perpustakaan, 1 orang S2 Perpustakaan, dan 9 lainnya adalah pustakawan melalui program pelatihan Calon Pustakawan Tingkat Ahli dan program impassing yang diselenggarakan oleh perpustakaan nasional(Komarudin et.al. 2019).

Secara rinci tabel di bawah ini memberkan gambaran kondisi pustakawan IAIN Kediri tahun 2019. 
Tabel 1. Kondisi Pustakawan 2019*

\begin{tabular}{|c|l|l|l|}
\hline NO & \multicolumn{1}{|c|}{ NAMA } & \multicolumn{1}{|c|}{ PENDIDIKAN } & \multicolumn{1}{|c|}{ KET. } \\
\hline 1. & Komarudin & S2-Ilmu Perpustakaan & Pustakawan \\
\hline 2. & Djuwandana Pamungkas & $\begin{array}{l}\text { S1 Non Perpustakaan } \\
\text { (Diklat Calon Pustakawan } \\
\text { Tingkat Ahli/CPTA) }\end{array}$ & Pustakawan \\
\hline 3. & Moch. Basit Aulawi & S1 Ilmu Perpustakaan & Pustakawan \\
\hline 4. & Achmad Muslih & S1 Non Perpustakaan & Pustakawan \\
\hline 5. & Evi Rahmawati & S1 Ilmu Perpustakaan & Pustakawan \\
\hline 6. & Muhamad Hamim & $\begin{array}{l}\text { S1-Komputer } \\
\text { (Diklat Calon Pustakawan } \\
\text { Tingkat Ahli) }\end{array}$ & Pustakawan \\
\hline 7. & Nurwarniatun & S-2 Non Perpustakaan & Pustakawan \\
\hline 8. & Imam Yanuar & S-1 Non Perpustakaan & Pustakawan \\
\hline 9. & Budi Dwi Santoso & S-1 Non Perpustakaan & Pustakawan \\
\hline 10. & Kusnadi & S-1 Non Perpustakaan & Pustakawan \\
\hline 11. & Aqul Mashuri & S-1 Non Perpustakaan & Pustakawan \\
\hline 12. & Yudi Sumarsono & SMA & Pustakawan \\
\hline
\end{tabular}

*Data diolah dari Administrasi Perpustakaan 2019

Data di atas menunjukkan bahwa latar belakang pendidikan pustakawan IAIN sangat beragam. SDM yang memiliki latar belakang keilmuan perpustakaan adalah 3 orang, selainnya menjadi pustakawan melalui diklat CPTA dan program impassing pustakawan yang diselenggarakan oleh Perpustakaan Nasional. Untuk mengembangkan kompetensi pustakawan, kegiatan-kegiatan pengembangan SDM yang diikuti pustkawan IAIN Kediri adalah:

1. Kompetensi Manajemen Perpustakaan

Kegiatan pengembangan kompetensi manajemen perpustakaan dilakukan baik di dalam maupun di luar negeri.Dalam kegiatan ini pustawakan berperan baik sebagai nara sumber maupun peserta. Kegiatan pengembangan SDM di dalam negeri diselenggarakan oleh Asosiasi Perpustakaan Perguruan Tinggi Islam (APPTIS) dalam bentuk TOT Pustakawan PT, dan Seminar Nasional dan Rakor APPTIS, sedangkan kegiatan di luar negeri dalam bentuk Development of Library System Management (DELSMA) yang diselengarakan oleh Direktorat Perguruan Tinggi Islam Kemenag RI.

2. Kompetensi pengolahan bahan pustaka

Kegiatan pengembangan kompetensi pengolahan bahan pustaka diselenggarakan oleh Perpustakaan Nasional dalam bentuk Koordinasi Pengembangan Koleksi Nasional 
yang diselenggarakan oleh Perpustakaan Nasional, Seminar Internasional Union Catalog OCLCyang diselenggarakan oleh Universitas Brawijaya, dan Pelatihan IOS Moraref yang diselengarakan oleh APPTIS dan Diktis Kemenag RI.Kegiatan-kegiatan ini sangat membantu pustakawan dalam mengembangkan koleksi dan merancang katalog induk sebagaimana disampaikan oleh M. Hamim:

Melalui kegiatan ini pustakawan di perguruan tinggi mampu mengelola katalog-katalogyang tersebar di berbagai perpustakaan fakultas dan program studiatau pusat-pusat kajian dijadikan satu secara on line, sehingga memudahkan dalam pengelolaan dan penelusuran (Muhammad 2019).

Pengembangan katalog induk adalah sebuah keharusan karena hanya dengan cara ini intergrasi data (katalog) adalah kebutuhan di era teknologi informasi ini, pernyataan ini secara eksplisit menunjukkan manfaat kegiatan pengembangan komptensi pustakawan untuk menjawab perkembangan dan tuntutan pengguna.

\section{Kompetensi IT}

Kegiatan pengembangan kompetensi IT diikuti oleh pustakawan baik sebagai nara sumber maupun peserta. Kegiatan-kegiatan pengembangan IT kebanyakan adalah pelatihan sistem otomasi perpustakaan menggunakan SLIMs.

4. Kompetensi penulisan karya ilmiah dan Daftar Usul Penetapan Angka Kredit (DUPAK) dan Literasi Informasi

Kegiatan pengembangan kompetensi karya ilmiah dan DUPAK diikuti oleh seluruh pustakawan IAIN Kediri dan diselenggarakan oleh perpustakaan IAIN Kediri sendiri.Kegiatan ini sangat bermanfaat untuk mengembangkan kompetensi pustakawan sebagaimana di sampaikan oleh M. Hamim:

Kegiatan literasi informasi sangat membantu pustakawan untuk menelusur informasi yang baik, mengolah informasi dari sumbersumber online dan mampu mengaplikasikannya ke dalam karya ilmiah. Apalagi kecendrungan pengguna kita hari ini pada sumbersumber online(Muhammad 2019).

\section{Kompetensi soft skills}

Kegiatan pengembangan kompetensi soft skills pustakawan diselenggarakan oleh Perpustakaan UIN Malang.Secara rinci berikut ini adalah tabel kegiatan pengembangan SDM pustakawan yang diikuti oleh pustakawan IAIN Kediri mulai tahun 2013-2019.

Tabel 2. Kegiatan Pengembangan Kompetensi Pustakawan 2013-2019

\begin{tabular}{|l|l|c|l|l|}
\hline No & \multicolumn{1}{|c|}{ BentukKegiatan } & Tahun & \multicolumn{1}{c|}{ Nama } & \multicolumn{1}{c|}{ Tempat } \\
\hline 1 & $\begin{array}{l}\text { Narasumber Rakor } \\
\text { Perpustakaan Sekolah }\end{array}$ & 2013 & Komarudin & $\begin{array}{l}\text { KPAD Kota } \\
\text { Kediri }\end{array}$ \\
\hline 2 & $\begin{array}{l}\text { Narasumber } \\
\text { ProgramPengembangan budaya } \\
\text { baca dan pembinaan } \\
\text { Perpustakaan Kelurahan Se }\end{array}$ & 2013 & Komarudin & $\begin{array}{l}\text { KPAD Kota } \\
\text { Kediri }\end{array}$ \\
\hline
\end{tabular}




\begin{tabular}{|c|c|c|c|c|}
\hline & Kota Kediri & & & \\
\hline 3 & $\begin{array}{l}\text { Narasumber Workshop } \\
\text { membangun Perpustakaan } \\
\text { berbasis TI }\end{array}$ & 2013 & Komarudin & $\begin{array}{l}\text { Perpustakaan } \\
\text { IAIN } \\
\text { Tulungagung. }\end{array}$ \\
\hline 4 & $\begin{array}{l}\text { Sebagai Peserta Temu } \\
\text { Pustakawan bersama Sekjen IPI } \\
\text { Pusat }\end{array}$ & 2013 & Komarudin & $\begin{array}{l}\text { UPT } \\
\text { Perpustakaan } \\
\text { Bung Karno }\end{array}$ \\
\hline 5 & $\begin{array}{l}\text { Peserta Workshop } \\
\text { pengembangan perpustakaan } \\
\text { dengan aplikasi SLIMs }\end{array}$ & 2013 & M.BasitAulawi & $\begin{array}{l}\text { Perpustakaan } \\
\text { STAIN } \\
\text { Pamekasan. }\end{array}$ \\
\hline 6 & Narasumber Instalasi SLIMs & 2013 & $\begin{array}{l}\text { Muhamad } \\
\text { Hamim, }\end{array}$ & $\begin{array}{l}\text { Stikes Ganesa } \\
\text { Husada. }\end{array}$ \\
\hline 7 & $\begin{array}{l}\text { Peserta Pelatihan Manajemen } \\
\text { Perpustakaan Berbasis TI }\end{array}$ & 2013 & $\begin{array}{l}\text { Muhamad } \\
\text { Hamim }\end{array}$ & $\begin{array}{l}\text { PusatPerpustak } \\
\text { aan UIN } \\
\text { Maliki } \\
\text { Malang. }\end{array}$ \\
\hline 8 & $\begin{array}{l}\text { Peserta Sosialisasi sertifikasi } \\
\text { pustakawan dan akreditasi } \\
\text { kelembagaan perpustakaan }\end{array}$ & 2014 & Komarudin & BPAD Jatim. \\
\hline 9 & $\begin{array}{l}\text { Narasumber Rakor } \\
\text { Pengembangan perpustakaan }\end{array}$ & 2014 & M.BasitAulawi & $\begin{array}{l}\text { KPAD Kota } \\
\text { Kediri. }\end{array}$ \\
\hline 10 & $\begin{array}{l}\text { Peserta Seminar Internasional } \\
\text { Union Catalog OCLC }\end{array}$ & 2014 & Evi Rahmawati & $\begin{array}{l}\text { Perpustakaan } \\
\text { UB. }\end{array}$ \\
\hline 11 & $\begin{array}{l}\text { Peserta Workshop Pengelolaan } \\
\text { Institusional Repository } \\
\text { Berbasis Eprints }\end{array}$ & 2015 & Komarudin & $\begin{array}{l}\text { Perpustakaan } \\
\text { STAIN } \\
\text { Ponorogo }\end{array}$ \\
\hline 12 & $\begin{array}{l}\text { Peserta Development of Library } \\
\text { System Management } \\
\text { (DELSMA) }\end{array}$ & 2016 & Komarudin & Australia \\
\hline 13 & $\begin{array}{l}\text { Peserta Workshop Penyusunan } \\
\text { DUPAK Pustakawan }\end{array}$ & 2017 & $\begin{array}{l}\text { Komarudin } \\
\text { M.BasitAulawi } \\
\text { Djuwandana } \\
\text { Pamungkas }\end{array}$ & $\begin{array}{l}\text { UIN } \\
\text { SunanAmpel } \\
\text { Surabaya }\end{array}$ \\
\hline 14 & $\begin{array}{l}\text { Peserta Development of Library } \\
\text { System Management } \\
\text { (DELSMA) }\end{array}$ & 2017 & $\begin{array}{l}\text { Muhamad } \\
\text { Hamim, }\end{array}$ & $\begin{array}{l}\text { Jerman ( Kota } \\
\text { Colen ) }\end{array}$ \\
\hline 15. & $\begin{array}{l}\text { Narasumber SLIMS } \\
\text { Community Meetup } 2017 \\
\text { (MembangunEkosisten Open } \\
\text { Source di Perpustakaan ) }\end{array}$ & 2017 & $\begin{array}{l}\text { Muhamad } \\
\text { Hamim, }\end{array}$ & $\begin{array}{l}\text { UGM } \\
\text { Yogyakarta. }\end{array}$ \\
\hline 16 & $\begin{array}{l}\text { Peserta Pelatihan } \\
\text { Pengembangan Soft skills Bagi } \\
\text { Staf Perpustakaan. }\end{array}$ & 2017 & $\begin{array}{l}\text { Muhamad } \\
\text { Hamim }\end{array}$ & $\begin{array}{l}\text { UIN Maliki } \\
\text { Malang. }\end{array}$ \\
\hline 17 & $\begin{array}{l}\text { Narasumber Workshop } \\
\text { Manajemen Perpustakaan } \\
\text { Berbasis Teknologi Informasi } \\
\text { Menggunakan Aplikasi SLIMs }\end{array}$ & 2017 & $\begin{array}{l}\text { Muhamad } \\
\text { Hamim }\end{array}$ & $\begin{array}{l}\text { DinasPerpusta } \\
\text { kaan Dan } \\
\text { ArsipKab. } \\
\text { Blitar. }\end{array}$ \\
\hline 18 & Peserta Modernize and & 2018 & Muhamad & Wisata Agro \\
\hline
\end{tabular}




\begin{tabular}{|c|c|c|c|c|}
\hline & $\begin{array}{l}\text { Transform yourData Center } \\
\text { with Dell EMC }\end{array}$ & & Hamim & $\begin{array}{l}\text { Wonosari- } \\
\text { Lawang }\end{array}$ \\
\hline 19. & $\begin{array}{l}\text { PesertaRelawan TIK Indonesia } \\
\text { Kota Kediri Bekerjasama dgn } \\
\text { ICT Watch Indonesia-Dinas } \\
\text { Kominfo Kota Kediri }\end{array}$ & 2018 & $\begin{array}{l}\text { Muhamad } \\
\text { Hamim }\end{array}$ & $\begin{array}{l}\text { Relawan TIK } \\
\text { Kediri }\end{array}$ \\
\hline 20. & $\begin{array}{l}\text { Se Peserta Seminar Nasional, } \\
\text { Pusat Perpustakaan UIN Sunan } \\
\text { Gunung Djati Bandung, } \\
\text { bekerjasama dengan Asosiasi } \\
\text { Perpustakaan Tinggi Islam }\end{array}$ & 2018 & $\begin{array}{l}\text { Muhamad } \\
\text { Hamim }\end{array}$ & $\begin{array}{l}\text { UIN SGD } \\
\text { Bandung }\end{array}$ \\
\hline 21. & $\begin{array}{l}\text { Narasumber Workshop } \\
\text { OtomasiPerpustakaan } \\
\text { Madrasah }\end{array}$ & 2018 & $\begin{array}{l}\text { Muhamad } \\
\text { Hamim }\end{array}$ & $\begin{array}{l}\text { UIN } \\
\text { SunanAmpel } \\
\text { Surabaya. }\end{array}$ \\
\hline 22. & $\begin{array}{l}\text { Peserta "TOT" } \\
\text { PustakawanPerguruan Tinggi }\end{array}$ & 2018 & $\begin{array}{l}\text { Muhamad } \\
\text { Hamim }\end{array}$ & $\begin{array}{l}\text { UIN } \\
\text { SunanKalijaga } \\
\text { Yogyakarta. }\end{array}$ \\
\hline 23. & Peserta SLIMS COMMEETUP & 2018 & $\begin{array}{l}\text { Muhamad } \\
\text { Hamim }\end{array}$ & $\begin{array}{l}\text { UniversitasKat } \\
\text { olikWidya } \\
\text { Mandala } \\
\text { Surabaya. }\end{array}$ \\
\hline 24. & $\begin{array}{l}\text { Peserta Worshop Literasi } \\
\text { Informasi }\end{array}$ & 2018 & $\begin{array}{l}\text { Muhamad } \\
\text { Hamim } \\
\text { Nurwarniatun } \\
\text { EviRahmawati }\end{array}$ & $\begin{array}{l}\text { Pasca Sarjana } \\
\text { IAIN Kediri }\end{array}$ \\
\hline 25. & $\begin{array}{l}\text { Peserta Workshop Karya Ilmiah } \\
\text { selama } 2 \text { hari }\end{array}$ & 2018 & $\begin{array}{l}\text { Semua } \\
\text { pustakawan } \\
\text { IAIN Kediri }\end{array}$ & IAIN Kediri \\
\hline 26. & $\begin{array}{l}\text { Peserta konggres XIV Ikatan } \\
\text { Pustakawan Indonesia Dan } \\
\text { Seminar Ilmiah }\end{array}$ & 2018 & Komarudin & IPI \\
\hline 27. & $\begin{array}{l}\text { Peserta Seminar Nasional \& } \\
\text { Rakernas APPTIS }\end{array}$ & 2019 & $\begin{array}{l}\text { Komarudin } \\
\text { M.Basit } \\
\text { Aulawi }\end{array}$ & $\begin{array}{l}\text { UPT } \\
\text { Perpustakaan } \\
\text { IAIN Kudus. }\end{array}$ \\
\hline 28. & $\begin{array}{l}\text { Sebagai Peserta Pelatihan IOS- } \\
\text { Moraref }\end{array}$ & 2019 & $\begin{array}{l}\text { Komarudin } \\
\text { M.BasitAulawi } \\
\text { Muhamad } \\
\text { Hamim }\end{array}$ & $\begin{array}{l}\text { UPT } \\
\text { Perpustakaan } \\
\text { IAIN Kudus. }\end{array}$ \\
\hline 29. & $\begin{array}{l}\text { Sebagai Peserta Rapat } \\
\text { Koordinasi Pengembangan } \\
\text { Koleksi Nasional }\end{array}$ & 2019 & Komarudin & Perpusnas R.I. \\
\hline
\end{tabular}

Memperhatikan tabel di atas kegiatan pengembangan SDM pustakawan semuanya adalah Kegiatan Non Formal yaitu ditempuh dengan cara mengikuti pendidikan dan pelatihan (diklat), penataran (up grading), symposium, seminar, lokakarya, kursus, magang (on the job training), studi banding dan lain sebagainya yang tentunya bersifat pendidikan non-formal. 
Dari 29 kegiatan tersebut, hanya ada 2 kegiatan yang dilaksanakan oleh perpustakaan dan IAIN Kediri, yaitu workshop Penulisan karya ilmiah dan DUPAK; dan workshop literasi informasi.

Selain kegiatan-kegiatan di atas perpustakaan secara internal juga menyelengarakan kegiatan informal dalam bentuk pendampingan bagi para pustakawan baru dalam melakukan kegiatan-kegiatan kepustakawan, seperti langkah-langkah dalam klasifikasi buku, dan jurnal. Namun sayangnya kegiatan pendampingan belum bisa dilakukan secara sistematis dan terjadwal, sehingga hasilnya belum bisa maksimal. (Komarudin 2019).

Hal ini menunjukkan bahwa kegiatan pengembangan SDM perpustakaan IAIN belum direncanakan secara sistematis sebagai bagian yang menyatu dengan kegiatan perpustakaan IAIN Kediri.

\section{Kendala-kendala Pengembangan SDM}

\section{Kemampuan Dasar Kepustakawanan Beragam}

Kemampuan pustakawan dalam hal dasar-dasar kepustakawan tidak seragam karena ada beberapa jalur untuk menjadi pustakawan, bisa karena memiliki latar belakang pendidikan ilmu perpustakaan, bisa melalui Pendidikan Calon Pustakawan Tingkat Ahli (CPTA), atau melalui jalur impassing yang diselenggarakan oleh Perpustakaan Nasional. Jalur-jalur tersebut menjadikan kesulitan tersendiri dalam hal pengembangan SDM pustakawan. Hal ini sebagaimana disampaikan oleh Komarudin:

Penguasaan dasar-dasar kepustakawan belum seragam sehingga tugastugas tertentu tidak bisa dialihkan kepada pustakawan yang lain, misalnya pengolahan bahan pustaka. Dalam beberapa tahun tugas pengolahan bahan pustaka tidak dialihkan ke pustakawan lain(Komarudin 2019).

Pernyataan di atas semakin meneguhkan bahwa pengembangan SDM pustakawan perlu direncanakan dengan baik,karena penguasaan pustakawan terhadap dasar-dasar kepustakawan adalah kompetensi dasar yang harus dikuasai oleh semua pustakawan apalagi di pustakawan di lingkungan perguruan tinggi.

Akibat dari beragamnya penguasaan pustakawan IAIN Kediri terhadap dasar-dasar ilmu kepustakawan menyebabkan pelaksanaan kegiatan sehari-hari menemui kendala, misalnya dalam hal pengelolaan artikel, sebagaimana di sampaikan M. Hamim:

Belum semua pustakawan bisa bagaimana mengelola data-data artikel dari jurnal atau majalah, sementara sebagai pustakawan PT kemampuan itu harus dimilikinya, karena mereka harus mendampingi mahasiswa untuk mencari, memilih dan pengelola artikel dalam rangka menyelesaikan tugas-tugas perkuliahan. Di samping itu sebagai pustakawan, dia juga harus menyusun karya ilmiah. (Muhammad 2019).

Di sinilah pentingnya perpustakaan untuk merancang kegiatan pengembangan pustakawan yang sistematis dan berkelanjutan sehingga kemampuan dasar pustakawan IAIN terdiri bisa semakin meningkat sesuai dengan kebutuhan di perpustakaan IAIN Kediri. 
2. Pustakawan belum menguasai aplikasi dasar sistem informasi

Karena beragamnya kompetensi pustakawan, beberapa pustawakan yang dikirim ke pelatihan belum menguasai aplikasi dasar sistem informasi, sehingga kegiatan-kegiatan pelatihan yang mestinya bisa diikuti tidak bisa diikuti karena persyaratan kompetensi yang harus dimiliki tersebut. Di sisi lain sejumlah kegiatan pelatihan yang tidak mensyaratkan kompetensi kemampuan dasar komputer, ketika materi pelatihan ternyata ada sebagaian materi tentang komputer menjadikan peserta tersebut tidak bisa mengikuti materi yang disampaikan selama pelatihan. Kendala ini juga akan berlanjut ketika yang bersangkutan selesai mengikuti materi dan diminta mempresentasikan hasil pelatihan yang diikutinya. Hal ini sebagaimana disampaikan oleh Komarudin:

Kemampuan dasar komputer memang menjadi kendala dalam pelatihanpelatihan yang diikuti oleh pustakawan. Karena kegiatan-kegiatan pendidikan dan pelatihan tentang perpustakaan hampir bisa dipastikan ada materi tentang teknologi informasi, misalnya pelatihan perpustakaan(Komarudin 2019).

Pernyataan tersebut mengindikasikan perlunya memperbanyak pelatihan-pelatihan IT bagi pustakawan, mengingat perkembangan IT sudah sedemikian pesat, begitu juga dengan realitaspengguna perpustakaan saat ini-terutama mahasiswa-tidak bisa dipisahkan dengan IT. Artinya IT sudah menjadi bagian hidup yang tak bisa dipisahkan dari kehidupan mereka.

\section{Pustakawan tidak percaya diri sehingga minim tindak lanjut}

Peran pustakawan PT sebagai mitra pemustaka mengharuskan dia memiliki sikap percaya diri, karena harus berinteraksi dengan mahasiswa, dosen, peneliti dan tenaga kependidikan. Untuk itu pustakawan harus terus meningkatkan kompetensinya, termasuk dalam hal ini kemampuan berkomunikasi. Dengan kemampuan berkomunikasi yang baik, ia akan menjadi mitra yang dengan mudah bisa menjelaskan ihwal perpustakaan kepada pengguna. Termasuk dalam kemampuan berkomunikasi adalah kemampuan presentasi di hadapan khalayak.

Ketika para pustakawan selesai mengikuti pelatihan, ia harus memprepesentasikan hasilnya kepada sesama pustawakan dan pada saat-saat tertentu harus mempresentasikannya di depan mahasiswa dan dosen. Namun karena kurangnya kepercayaan diri pustakawan, pelatihan-pelatihan yang telah diikuti tidak dapat disampaikan dengan baik kepada sesama pustakawan atau kepada mahasiswa dan dosen sebagai pengguna perpustakaan. Inilah pentingnya para pustakawan terus mengasah kemampuannya dalam berkomunikasi, sehingga peran dia sebagai mitra peneliti, mitra dosen dan mitra mahasiswa bisa dicapai. Hal ini sebagaimana disampaikan oleh Komarudin:

Di antara kendala dalam pengembangan pustakawan adalah kekurangpercayaan diri pustakawan dalam menyampaikan buah-buah pikirannya. Materi-materi tertentu sudah dikuasai oleh para pustakawan, misalnya materi tentang online research skill (penelusuran dan pengelolaan hasil penelusuran artikel, e-book dan informasi lainnya), namun karena pustakawan merasa dirinya belum selevel dengan dengan peneliti, materi yang dikuasainya tidak bisa tersampaikan dengan baik. (Komarudin 2019). 


\section{Terbatasnya Anggaran}

Hal ini terjadi di antaranya karena minimnya anggaran pengembangan SDM di Perpustakaan Kediri, sebagaimana disampaikan oleh Kepala Perpustakaan IAIN Kediri:

Kegiatan pengembangan SDM oleh internal perpustakaan IAIN Kediri memerlukan anggaran yang cukup besar, sementara anggaran dari internal IAIN Kediri sangat terbatas, sehingga cara yang bisa diditempuh adalah dengan mengirimkan pustakawan untuk mengikuti kegiatan yang diselenggaraan oleh pihak luar. (Komarudin 2019).

Pernyataan yang sama disampaikan oleh Basit Aulawi,

Di antara kendala pengembangan pustakawan adalah terbatasnya dana, sehingga pustakawan harus pro aktif untuk mengikuti pelatihanpelatihan dengan biaya pribadi, atau belajar tutorial melalui internet. Sehingga keterbatasan anggaran tidak menjadi masalah untuk mengembangkan kompetensi (Aulawi 2019).

Dengan demikian masalah minimnya anggaran pengembangan SDM bisa dicarikan jalan keluar melalui kreatifitas pustakawan untuk mengembangkan diri, seperti dengan belajar sendiri. Jadi kata kuncinya adalah kemauan dan kreatifitas pustakawan untuk mengejar ketertinggalannya melalui berbagai kegiatan.

5. Perpustakaan tidak otonom dalam merencanakan kegiatan pengembangan SDM

Posisi perpustakaan yang berada dibawah lembaga induknya sulit memiliki otonomi dalam merancang kegiatan-kegiatan pengembangan, termasuk di dalamnya kegiatan pengembangan SDM. Hal ini sebagaimana disampaikan oleh Komarudin:

Perencanaan kegiatan-kegiatan pengembangan SDM telah kami lakukan namun karena kita tidak bisa memutuskan sendiri kegiatan tersebut, makanya apa yang telah kami rencanakan dalam pengembangan SDM sebatas usulan kepada pimpinan di atas kita. (Komarudin 2019).

Pernyataan di atas menyiratkan pentingnya kemampuan negosiasi kepada pimpinan sehingga kegiatan-kegiatan pengembangan SDM bisa direalisasikan oleh pimpinan. Perpustakaan juga bisa mencari alternatif lain misalnya dengan mengikuti kursus-kursus online sehingga masalah bisa keterbatasan anggaran pengembangan SDM pustakawan ini ada solusinya.

\section{E. KESIMPULAN}

Kegiatan-kegiatan pengembangan SDM pustakawan di IAIN Kediri bertujuan untuk meningkatkan kompetensi kepustakawaan, seperti manajemen, pengolahan dan pelayanan perpustakaan. Kegiatan pengembangan pustakawan dilakukan baru pada kegiatan informal dan non formal.

Mulai tahun 2013-2019 terdapat 29 kegiatan pengembangan SDM, kegiatan-kegiatan tersebut bisa dikelompokkan menjadi: kompetensi manajemen perpustakaan, kompetensi pengolahan bahan pustaka, kompetensi IT, Kompetensi penulisan karya ilmiah dan Daftar 
Usul Penetapan Angka Kredit (DUPAK) dan Literasi Informasi, dan terakhir kompetensi softskills.

Sedangkan kendala Pengembangan SDM pustakawan IAIN Kediri yaitu: kemampuan pustakawan dalam hal dasar-dasar kepustakawanan sangat beragam, Pustakawan belum menguasai aplikasi dasar sistem informasi, Pustakawan tidak percaya diri sehingga minim tindak lanjut, minimnya anggaran pengembangan SDM, dan perpustakaan tidak otonom dalam merencanakan kegiatan pengembangan SDM.

\section{DAFTAR PUSTAKA}

Aulawi, M. Basit. 2019. Kendala Pengembangan SDM Pustakawan.

Komarudin. 2019. Kendala Pengembangan SDM Pustakawan IAIN Kediri.

Komarudin et.al. 2019. Panduan Perpustakaan IAIN Kediri. Kediri: Perpustakaan IAIN Kediri.

Laila, Rahmawati. 2012. "Peran Pustakawan Perguruan Tinggi Dalam Era Informasi Dan Digitalisasi." Jurnal Ta'lim II: 105-33.

Muhammad, Hamim. 2019. Kendala Pengembangan SDM Pustakawan IAIN Kediri.

Nugrahani, Romdha. 2017. "Manajemen Sumber Daya Manusia Perpustakaan Perguruan

Tinggi Untuk Mewujudkan Sumber Daya Manusia Yang Berkualitas.” Warta

Perpustakaan Pusat Undip 10 (2).

https://ejournal2.undip.ac.id/index.php/wp/article/view/1776.

Perpustakaan Nasional RI. 2011. Standar Nasional Perpustakaan (SNP) 010: 2011.

Rachman Hermawan S, and Zulfikar Zen. 2006. Etika Kepustakawanan: Suatu Pendekatan Terhadap Profesi Dan Kode Etik Pustakawan Indonesia. Cet. 1. Jakarta: Sagung Seto.

Rifngati, Endang. 2016. "Tantangan Pustakawan Perguruan Tinggi Dalam Memberikan Layanan Prima Dengan Berbasis Teknologi Informasi." Dinamika Penelitian: Media Komunikasi Penelitian Sosial Keagamaan 16 (2): 268-273-273. https://doi.org/10.21274/dinamika.2016.16.2.268-273.

Rizal Saiful-Haq. 2005. Pengantar Manajemen Perpustakaan Madrasah. Jakarta: Fakultas Adab dan Humaniora UIN Syarif Hidayatullah.

Sudiarta, I. Ketut. 2016. "Manajemen Sumber Daya Manusia Perpustakaan (Studi Kasus Di Perpustakaan Universitas Hindu Indonesia).” Jurnal Ilmiah Mahasiswa D3 Perpustakaan. https://ojs.unud.ac.id/index.php/d3perpus/index.

Sutarno NS. 2006. Manajemen Perpustakaan: Suatu Pendekatan Praktek. 1st ed. Jakarta: Sagung Seto.

Suwarno, Wiji. 2016. "Mengembangkan SDM Perpustakaan Dalam Rangka Menuju World Class University.” LIBRARIA: Jurnal Perpustakaan 4 (1). http://journal.stainkudus.ac.id/index.php/Libraria/article/view/1241.

Undang-Undang Nomor 43 Tentang Perpustakaan. 2007. 